\title{
Simple does not mean poor: grasslands and forests harbor similar ant species richness and distinct composition in highlands of southern Brazil
}

\author{
Cristian Luan Klunk ${ }^{1,2}$, Eduardo Luís Hettwer Giehl, Benedito Cortês Lopes ${ }^{1}$, \\ Frederico Rottgers Marcineiro ${ }^{I}$ \& Félix Baumgarten Rosumek ${ }^{1,3}$ *i] \\ ${ }^{1}$ Universidade Federal de Santa Catarina, Departamento de Ecologia e Zoologia, Florianópolis, SC, Brasil \\ ${ }^{2}$ Universidade Federal do Paraná, Programa de Pós Graduação em Ecologia e Conservação, Setor de Ciências \\ Biológicas, Curitiba, PR, Brasil \\ ${ }^{3}$ Technische Universität Darmstadt, Ecological Networks, Darmstadt, Deutschland \\ *Corresponding author: Félix Baumgarten Rosumek, e-mail: rosumek@hotmail.com
}

KLUNK, C. L., GIEHL, E. L. H., LOPES, B. C., MARCINEIRO, F. R., ROSUMEK, F. B. Simple does not mean poor: grasslands and forests harbor similar ant species richness and distinct composition in highlands of southern Brazil. Biota Neotropica. 18(3) e20170507. http://dx.doi.org/10.1590/1676-0611-BN-2017-0507

\begin{abstract}
Several studies addressed ant communities in the dense Atlantic Forest that runs along the Brazilian coast. However, comparatively little is known about the mixed forests and grasslands that occur in the southern range of the Atlantic Forest domain. In this study we performed the first standardized assessment of ants in the forestgrassland mosaic found in the highlands of the state of Santa Catarina. We aimed to investigate and compare ant richness and composition between mixed forests and grasslands in the main mountain range of south Brazil. Ants were collected in two years with ground pitfalls, tree pitfalls and litter samples. Sixty ant species were recorded, resulting in 22 new records for "Planalto Serrano" region and three for the state of Santa Catarina: Eurhopalothrix depressa, Pheidole radoszkowskii and Wasmannia williamsoni. There was significant dissimilarity in ant species composition between grasslands and forests, but no difference in ant species richness, even considering the higher number of strata in mixed forests. Similar richness and low number of arboreal species suggest that this ant community is structured similarly to temperate ones. Both habitats presented a large proportion of exclusive species. The fact that species composition between grassland and forest areas differed, coupled with the similarity in species richness between habitats and the record of new ant species for the region, calls for strong conservation efforts in grasslands of southern Brazil, which still are little protected by conservation areas.

Keywords: Formicidae, Atlantic Forest, Araucaria Forest, PPBio da Mata Atlântica, Eurhopalothrix depressa, Wasmannia williamsoni.

\section{Simples não significa pobre: campos e florestas abrigam riqueza similar e composições distintas de espécies de formiga em regiões altas do sul do Brasil}

Resumo: Diversos estudos já foram realizados com comunidades de formigas nas regiões de Floresta Ombrófila Densa que ocorrem ao longo da costa do Brasil. Comparativamente menos é conhecido sobre as Florestas Ombrófilas Mistas e campos que ocorrem na parte meridional do domínio da Mata Atlântica. Neste estudo nós realizamos o primeiro levantamento padronizado de formigas no mosaico de florestas e campos que ocorre nas regiões altas de Santa Catarina. Nosso objetivo foi investigar e comparar a riqueza e composição de espécies entre florestas e campos na principal cordilheira do sul do Brasil. Formigas foram coletadas em dois anos com armadilhas de queda no solo e nas árvores, e com amostras de serapilheira. Sessenta espécies foram registradas, constituindo 22 novos registros para a região do Planalto Serrano e três para o estado de Santa Catarina: Eurhopalothrix depressa, Pheidole radoszkowskii e Wasmannia williamsoni. A composição de espécies diferiu significativamente entre florestas e campos, mas não houve diferença em riqueza de espécies, mesmo considerando o maior número de estratos nas florestas. Riqueza similar e pequeno número de espécies arbóreas sugere que esta comunidade é estruturada de modo semelhante às comunidades de regiões temperadas. Ambos os habitats apresentaram alta proporção de espécies exclusivas. $\mathrm{O}$ fato de que a composição foi diferente, somado à similaridade em riqueza de espécies entre habitats e ao registro de novas espécies, indica a necessidade de maiores esforços conservacionistas nos campos do Sul do Brasil, que ainda são pouco protegidos por unidades de conservação.

Palavras-chave: Formicidae, Mata Atlântica, Floresta de Araucária, PPBio da Mata Atlântica, Eurhopalothrix depressa, Wasmannia williamsoni. 


\section{Introduction}

Brazil is one of the most biodiverse countries in the world, due to its high diversity of ecosystems, many containing a high number of endemic species (Lewinsohn \& Prado 2003). The Atlantic Forest runs from northeast to south Brazil and its considered one of the world's eight main hotspots of biodiversity (Myers et al. 2000). It harbors a multitude of vegetation types under its domain, such as highland mixed forests on the southern border of its distribution (IBGE 2012). Highland mixed forests, or "Araucaria forests", are constituted by a mixture of tropical and temperate flora and are characterized by the occurrence of the endemic Araucaria angustifolia (Bertol.) Kuntze, one of the few gymnosperm trees native to Brazil (Gasper et al. 2013). However, in areas of high altitude, forests are sharply interrupted by grasslands patches, resulting in mosaics of variable habitat complexity (Klein 1978). Here, we define habitat complexity as the vertical variation in habitat physiognomy (August 1983). Forests can be considered habitats with higher degree of complexity in relation to grasslands, due to the presence of several strata (ground, litter, understory, canopy) and more heterogeneous distribution of abiotic conditions and resources.

Grasslands occurring in highlands of southern Brazil are considered a remnant of the Glacial, Early and Mid-Holocene period, when the cold weather favored grasslands instead of forests (Behling \& Pillar 2007). Nowadays, forests have been slowly expanding over grasslands, but these persist because of a complex set of drivers (Silva \& Anand 2011). Even though grasslands are considered important sources of regional biodiversity, they are frequently neglected on the conservation agenda (Overbeck et al. 2007, Overbeck et al. 2015). In addition, out of the few studies about conservation biology directed to grasslands in the highlands of southern Brazil, most have addressed the protection of endemic grassland plants (e.g. Overbeck et al. 2007). Less works called attention to animal species, which also occur as endemic in grasslands around the world (Bond \& Parr 2010). Thus, surveys of arthropods richness and abundance can provide interesting data about the value of such grasslands for the conservation of animal diversity (Albuquerque \& Diehl 2009, Azcárate \& Peco 2012, Rosado et al. 2012, Diehl et al. 2014).

Ants are an important component of most terrestrial ecosystems, showing high richness and abundance, and displaying many ecological associations with plants and other animals (Ness et al. 2010). Because ant colonies are sessile, habitat structure is fundamental to determine food resources and availability of nesting sites (Blüthgen \& Feldhaar 2010), which results in ants being highly dependent on microhabitat conditions. Indeed, this strong relationship imply that ant species composition can be dissimilar between distinct phytophysiognomies that co-occur at the same site, such as in forest-grassland mosaics (Gibb \& Parr 2010).

Several studies addressed ant communities in the dense Atlantic Forest that runs along the Brazilian coast (a.k.a. Atlantic Forest stricto sensu or Atlantic Rainforest; e.g. Silva \& Lopes 1997, Freitas et al. 2014, Silva \& Brandão 2014). Comparatively little is known about highland mixed forests and grasslands (Ulysséa et al. 2011), which only recently started to be systematically investigated (Pinheiro et al. 2010, Dröse et al. 2017, Franco \& Feitosa 2018). We contributed to fill this knowledge gap with the first standardized assessment on the forest-grassland mosaic found in the highlands of the state of Santa Catarina, as a part of the "Programa de Pesquisa em Biodiversidade (PPBio) da Mata Atlântica" (Atlantic Forest Research Program on Biodiversity). Additionally, we compared ant species composition and richness between mixed forest and grasslands patches, with the hypothesis that ant distribution would be affected by habitat structure, thus leading to distinct assemblages coexisting in this mosaic.

\section{Methods}

\section{Study Area}

Fieldwork was carried out in "Parque Nacional de São Joaquim (PNSJ)" (28 8'53.07'S and 49 36’34.61'O), a national park which lies on the "Serra Geral" formation, the main mountain range of southern Brazil. The geology of this region is a result of volcanic sheds of basaltic lava that started $\sim 127$ million years ago (Milani et al. 2007). The climate in the region is $\mathrm{Cfb}$ following Köppen's classification (Alvares et al. 2014), with mean annual precipitation $\sim 1,400 \mathrm{~mm}$ and mean annual temperature $\sim 14^{\circ} \mathrm{C}$ (Fernandes \& Omena 2015). On winter, temperatures commonly fall below $0^{\circ} \mathrm{C}$ with occasional occurrence of snow (Nimer 1989).

The PNSJ has a total area of 49,300 ha and it is within the Atlantic Forest domain. Altitude of sampled plots ranged from 1,462 $\mathrm{m}$ to 1,671 $\mathrm{m}$. Samples were collected in two vegetation types, namely mixed forest ("Floresta Ombrófila Mista Alto-Montana") and grassland ("Campos do Planalto"). Grasslands are predominantly covered by a dense layer of herbaceous stratum, with occasional shrub patches and small isolated trees. Mixed forests have a canopy height of $\sim 8 \mathrm{~m}$, with emergent Araucaria angustifolia trees typically reaching $13 \mathrm{~m}$ (Rafael Barbizan Sühs, personal communication).

\section{Field Procedures}

Two field campaigns were conducted during summer, one in March 2014 and other in February 2015. Sampling was carried out on a rectangular grid of $5 \times 1 \mathrm{~km}$ with 10 plots, $1 \mathrm{~km}$ apart from each other (Figure S1 in Supplementary information). Each plot was 250 $\mathrm{m}$ long and followed the isocline of the ground. This design follows the RAPELD method for biodiversity surveys (Magnusson et al. 2005), implemented in the "PPBio Mata Atlântica". Five sampling points were established at each plot, $50 \mathrm{~m}$ apart from each other, totaling 50 sampling points. Nineteen sampling points were located in grasslands $\left(\mathrm{n}_{\mathrm{g}}\right)$ and 31 in forests $\left(\mathrm{n}_{\mathrm{f}}\right)$.

Ants were sampled with up to three methods, depending on the habitat structure of each sampling point (see Figure S2 in Supplementary information for detailed schematics). Ground pitfall traps were installed on all sampling points and retrieved after 48 hours. Each pitfall trap consisted on $300 \mathrm{ml}$ plastic cups with diameter of 7.2 $\mathrm{cm}$, buried at ground level, with a solution of water, detergent and salt as killing agent. Arboreal pitfalls followed the same design and were tied to trees at $1.5 \mathrm{~m}$ high, only in sampling points where there was at least one tree with more than $15 \mathrm{~cm}$ of diameter at breast height (DBH). Because of the low number of ants collected on arboreal pitfall traps in 2014, we added sardine baits to these traps in 2015. Additionally, in all sample points with accumulated leaf litter, we collected $1 \mathrm{~m}^{2}$ of 
it, three meters away from the ground pitfall. The litter was sifted on the field and later placed into Winkler extractors for 48 hours. Tree pitfalls and litter samples were collected mainly in forests, but also in a few grassland points whenever isolated trees/litter were available. All collected material was stored in ethanol $95 \%$.

\section{Laboratory Procedures}

For each sample, ants were initially sorted to morphospecies and at least one individual per morphospecies was mounted on paper triangles fixed in entomological pins. Ants were identified at genus level according to Palacio \& Fernández (2003). Species were identified with taxonomic keys and further compared with reference collections and AntWeb images (AntWeb 2017). Genus and species names were updated with Bolton (2017). When no taxonomic resources were available, they remained as morphospecies. All species identifications were revised by taxonomists of the "Laboratório de Sistemática e Biologia de Formigas" (Universidade Federal do Paraná) (see Acknowledgements). Voucher specimens are deposited in the reference collection of the "Laboratório de Biologia de Formigas" (ECZ, Universidade Federal de Santa Catarina).

The sources used for species-level identification were: Acromyrmex - Gonçalves (1961); Anochetus - Fernández (2008); Eurhopalothrix Longino (2013a); Gnamptogenys - Lattke et al. (2007); Heteroponera - Arias-Penna \& Fernández (2008); Linepithema - Wild (2007); Neivamyrmex - Watkins (1976); Octostruma - Longino (2013b); Oxyepoecus - Albuquerque \& Brandão (2004), Albuquerque \& Brandão (2009); Pachycondyla - Fernández (2008); Strumigenys - Bolton (2000); Trachymyrmex - Mayhé-Nunes \& Brandão (2005); Wasmannia - Longino \& Fernández (2007).

New species records were checked against the most recent checklist for Santa Catarina (Ulysséa et al. 2011) and the literature published afterwards.

\section{Data Analysis}

Data from the two field campaigns were merged for each sample point. We excluded from quantitative analyses data from one plot that was relocated between years. Therefore, the effective number of sampling points used in the analyses was 45,19 in grassland $\left(\mathrm{n}_{\mathrm{g}}\right)$ and 26 in forest areas $\left(\mathrm{n}_{\mathrm{f}}\right)$, including 45 ground pitfalls $\left(\mathrm{n}_{\mathrm{g}}=19, \mathrm{n}_{\mathrm{f}}=26\right)$, 29 tree pitfalls $\left(n_{\mathrm{g}}=6, \mathrm{n}_{\mathrm{f}}=23\right)$ and 27 litter samples $\left(\mathrm{n}_{\mathrm{g}}=1, \mathrm{n}_{\mathrm{f}}=26\right)$.

We calculated species frequency (number of records divided by total number of sampling points, calculated separately for each habitat) using presence-absence data, which is preferred to represent ant abundance (Longino 2000). To compare species richness between grassland and forest samples, we fitted curves of interpolation and extrapolation of Hill numbers to the split dataset, following the method developed by Chao et al. (2014) with order $\mathrm{q}=0$, which is the Hill number where there is zero weight for species abundances and thus stands for species richness. We built curves for ground pitfalls (the sampling method shared for all sampling points) and for all methods combined, which represents the sum of the strata available at each sample point. Interpolation and extrapolation curves were calculated with the R package "iNEXT" (Hsieh et al. 2016) and 95\% confidence intervals were estimated based on 1000 permutations. Comparison of confidence intervals was used to test for species richness differences between vegetation types. We compared curves both within the observed range of data and after extrapolating up to 50 sampling units within each vegetation type. Interpolated curves are important to smooth sampling effects in unbalanced designs as ours, while extrapolation allows the use of all sample units, and point out the expected behavior of the curves if a larger proportion of the community were sampled (Colwell et al. 2012).

To visualize differences in ant species composition among sampling points, we ran a Principal Coordinate Analysis (PCoA), using the package "vegan" (Oksanen et al. 2016). The PCoA was based on Jaccard similarities, using only ground pitfall records. To test the differences in composition between the two habitats, we calculated a Generalized Linear Model for multivariate response data $\left(\mathrm{GLM}_{\mathrm{mv}}\right)$ using the package "mvabund" (Wang et al. 2012). The GLM ${ }_{\mathrm{mv}}$ allows for choosing a family for the distribution of residuals. For species presence-absence data, the best option is to use the binomial distribution because it accounts for data with both lower and upper boundaries. Choosing an adequate distribution has the advantage that the GLMmv avoids confounding differences in location (true differences in species composition) and dispersion (differences due to changes in beta diversity; Wang et al. 2012). Specifically, the $\mathrm{GLM}_{\mathrm{mv}}$ has been shown to be more reliable to point out only location differences than traditional approaches, such as permutational multivariate analysis of variance - PERMANOVA, which can point out significant differences because of either location, dispersion, or even both patterns (Wang et al. 2012). Because GLM are more specific in terms of what their results tell, we can also be more confident in answering more specific questions, here whether there are differences in species composition, not beta diversity, between grassland and forest. We analyzed all data in R, version 3.3.2 (R Core Team 2016).

\section{Results}

We recorded 60 ant species belonging to nine subfamilies and 23 genera. Our survey adds 22 new species to the "Planalto Serrano" region list, including three new to Santa Catarina territory: Eurhopalothrix depressa, Pheidole radoszkowskii and Wasmannia williamsoni. Forty-six species were sampled in forests and 34 in grasslands (Table 1). Twenty-six species were exclusive to forests $(56 \%$ of the total for this vegetation), while 14 were exclusive to grasslands (41\%). The most frequent species in mixed forest was Heteroponera dentinodis (relative frequency $=0.81)$, followed by Oxyepoecus crassinodus $(0.73)$. In grassland, the most frequent species was Pheidole sp.5 (0.68), followed by Camponotus rufipes (0.53). Compared to ground pitfalls (40 spp.) and litter samples (42 spp.), tree pitfalls collected fewer species (11 spp.), and only two species were exclusively recorded by this method.

The interpolation curves based only on ground pitfalls showed a higher number of observed species in grasslands (Figure 1). However, with extrapolation, the curves tend to overlap, suggesting no actual difference between vegetation types. This richness equivalence is highlighted when we added data from leaf litter and tree pitfalls. With pooled data from all strata, the curves were similar and confidence intervals largely overlapped (Figure 2).

The GLM ${ }_{\mathrm{mv}}$ results showed a difference in species composition between grasslands and forests (Wald-value $=4.159 ; \mathrm{p}=0.034$ ). Most sampling points were separated in two groups corresponding to the two habitats, although there were intermediate sites that shared species from both habitats (Figure 3). 
Klunk, C.L. et al.

Table 1. Ant species recorded in "Parque Nacional de São Joaquim", southern Brazil. Frequencies represent number of records relative to number of sample points for each habitat (grasslands $=19$, forest $=26$ ). For methods, it is indicated whether the species was recorded or not with the method.

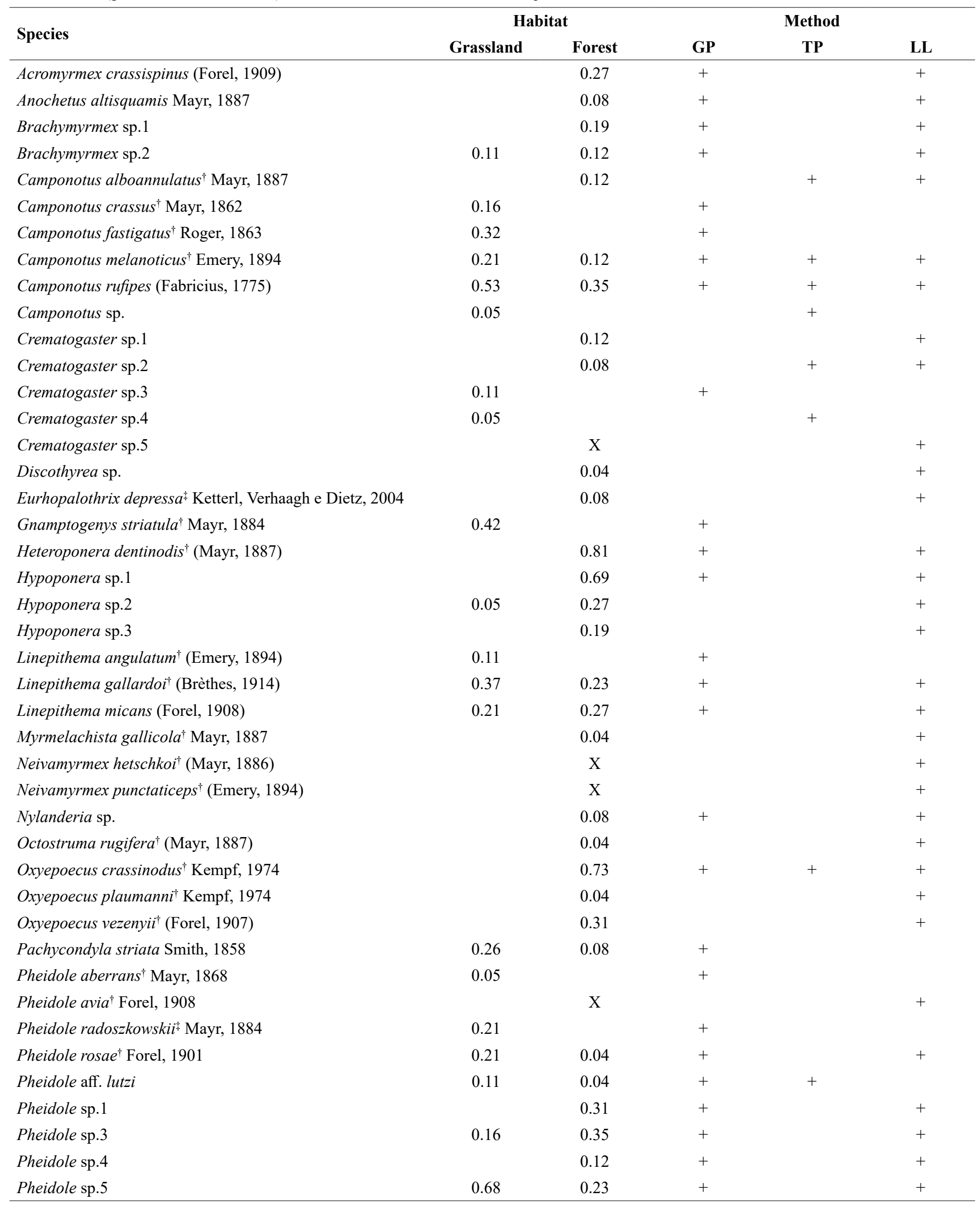


Continued Table 1.

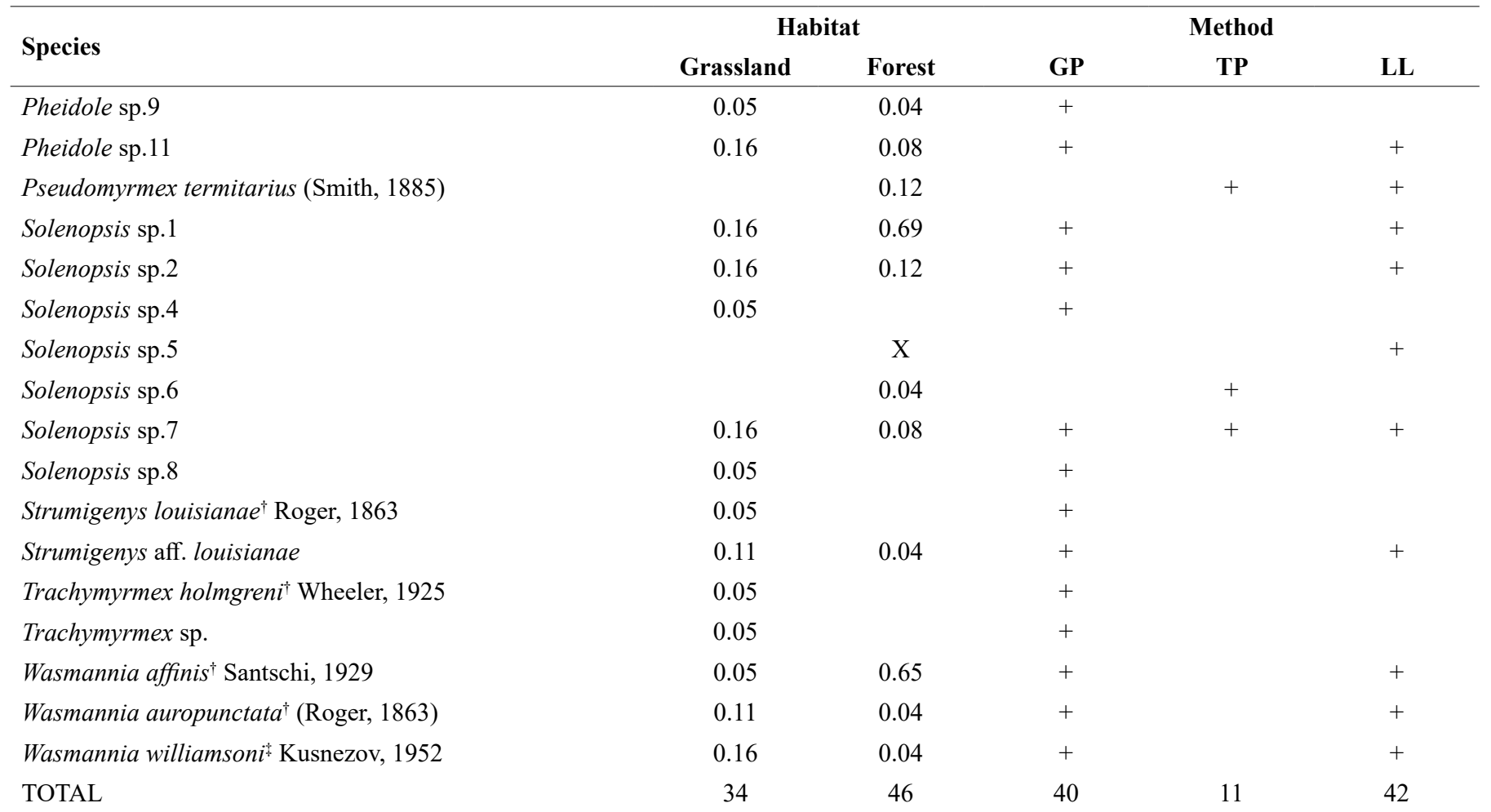

$\mathrm{X}=$ the species was recorded only on the plot removed from quantitative analyses. GP = ground pitfall traps. TP $=$ tree pitfall traps. LL $=$ leaf-litter samples. $\dagger=$ new records for the Planalto Serrano region. $t=$ new records for the state of Santa Catarina.

\section{Order $\mathrm{q}=0$}

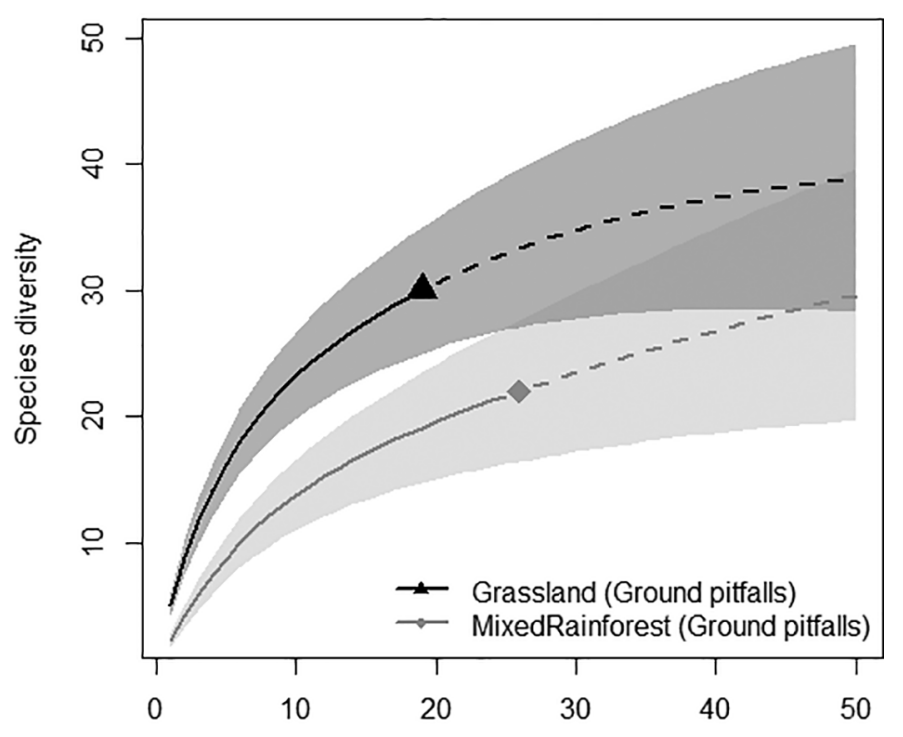

Number of sampling units

Figure 1. Interpolation, extrapolation and $95 \%$ confidence intervals of species richness in grassland and forest, using data from ground pitfall traps. Interpolation - solid lines; extrapolation - dashed lines.

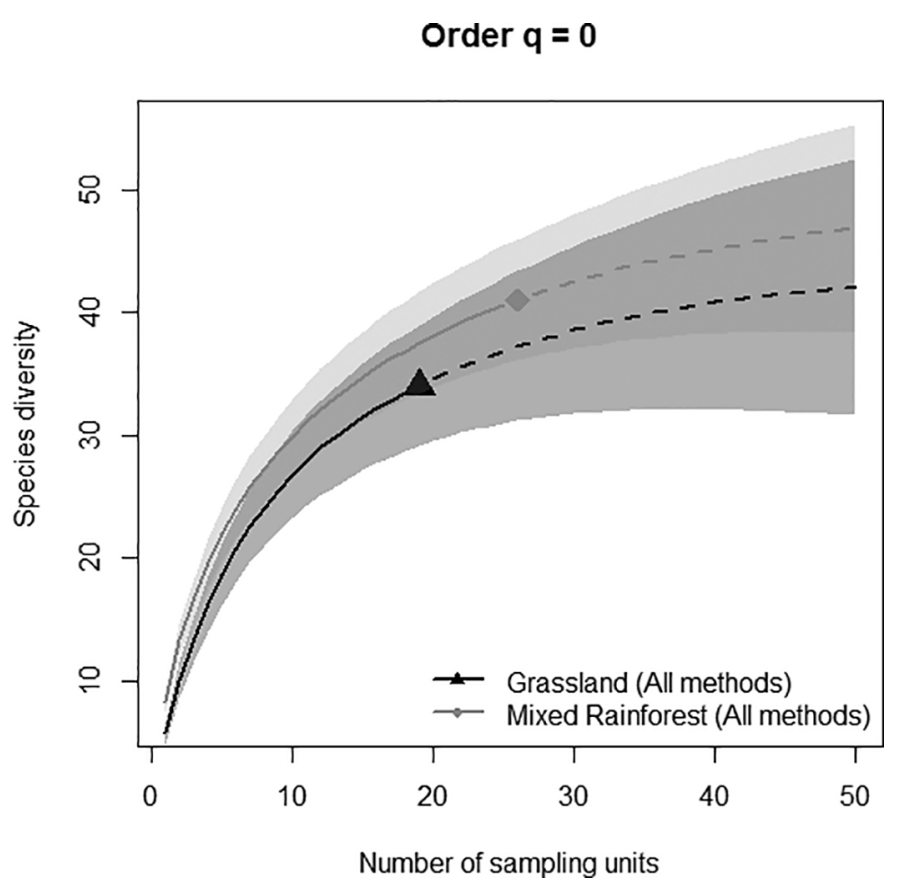

Figure 2. Interpolation, extrapolation and $95 \%$ confidence intervals of species richness in grassland and forest, using pooled data from all sampling methods. Interpolation - solid lines; extrapolation - dashed lines. 


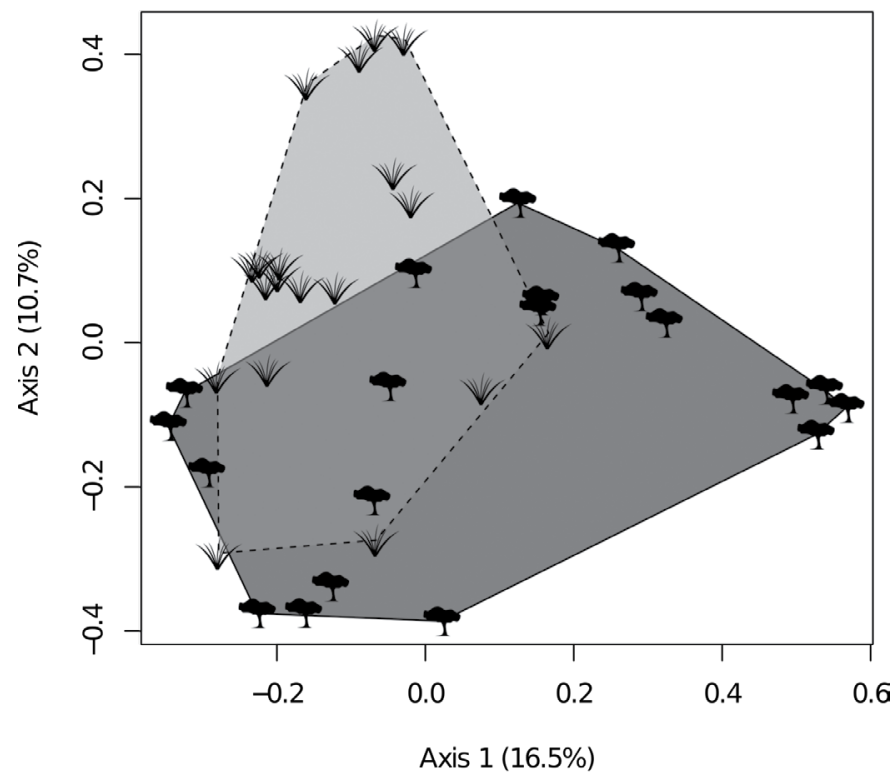

Figure 3. Principal Coordinate Analysis showing the dissimilarity of ant species composition between sites on grasslands or forests using data from ground pitfalls. Lines indicate convex hulls encompassing sites from each type of habitat (forests - solid line; grasslands - dashed line).

\section{Discussion}

\section{New regional records}

Santa Catarina is one of the few Brazilian states with a recent checklist of ant species recorded in its territory (Ulysséa et al. 2011). The "Planalto Serrano" region, where the PNSJ is located, was deemed as a research priority, with only 12 species recorded at the time (Ulysséa et al. 2011). The great number of new ant species in "Planalto Serrano" recorded here mainly is a result of this lack of knowledge, but also can be related to the complementarity of our sampling effort. The combination of pitfalls and leaf litter collection on the ground is strongly advised for biodiversity assessments (Alonso \& Agosti 2000, Bestelmeyer et al. 2000, King \& Porter 2005, Lopes \& Vasconcelos 2008), since the first method catch larger and more active species (Sabu et al. 2011), while the second is efficient to sample smaller and less active ants, including cryptic species (Fisher 1999). Finally, our sampling effort in grasslands sites, a poorly surveyed physiognomy until now in Santa Catarina, is another important source of those new records, a trend that is increasingly highlighted in other grasslands surveys of South Brazil recently published (Pinheiro et al. 2010, Rosado et al. 2012, Dröse et al. 2017, Franco \& Feitosa 2018).

With regard to the new records for the state of Santa Catarina, this is only the third known record for Eurhopalothrix depressa, previously found once in mixed forest, further south of our location, and once in dense Atlantic Forest (Ketterl et al. 2004). Considered a highly distinctive species of the genus (Longino 2013a), these few records suggest rarity and endemic distribution inside the Atlantic Forest domain. Little information is available about its biology, but most representatives of the genus are predators inside the leaf litter, where they are more often recorded (Longino 2013a). Wasmannia williamsoni is considered a grassland-associated species (Cuezzo et al. 2015), and indeed we found it more often in this vegetation. Although the previous authors suggested it to be a relict endemic lineage of the central region of Argentina, it was found in the Pampa region of southern Brazil (Rosado et al. 2012), and our record expands its distribution by $600 \mathrm{~km}$ further north. Finally, Pheidole radoszkowskii is a widespread species - or species complex - found all over the Neotropical region (Wilson 2003). Contrary to $E$. depressa, this record is likely result of the taxonomic uncertainty associated with most species of Pheidole.

\section{Species richness and composition}

A positive relationship between species richness and habitat complexity often is found in tropical and subtropical ant communities (Majer et al. 1997, Vasconcelos \& Vilhena 2006, but see Lassau \& Hochuli 2004). In lowland forests with higher canopy and strong presence of epiphytes, arboreal ants largely contribute to forest richness (Vasconcelos \& Vilhena 2006, Neves et al. 2013). However, this relationship might be found even when only the ground stratum is considered (Andersen 1986). The ground of a forest can be considered more complex and heterogeneous (Farji-Brener et al. 2004) than a grassland because of a litter layer with variable depth, more heterogeneous distribution of plants in the understory, and availability of tree-related resources (e.g. fallen fruits). In our study, ant richness was similar between habitats. This similarity was observed both when we compared pitfalls, and when we added data from other strata, which are characteristic of forests (leaf-litter, vegetation). A shift on the complexity-richness trend is common in temperate latitudes or high altitudes, where ant richness decline in shaded forests and increase in open habitats (Seifert 2007, Longino et al. 2014). Ants are thermophilic animals (Pie 2016) and, below a certain threshold, less species are able to tolerate low insolation and temperature inside forests. Even considering only grasslands, a decrease in species richness might be observed with altitude (Dröse et al. 2017). Thus, although most species we found also occur in dense Atlantic Forest, the community is organized differently, and some species change their behavior accordingly. This might be the case for Gnamptogenys striatula and Pachycondyla striata, two species very common inside lowland forests (Lattke 1995, Rosumek et al. 2008, Medeiros \& Oliveira 2009), which shifted their occurrence mainly to open areas in our study site.

A similar environmental effect reduces richness and abundance of arboreal-nesting ants in temperate habitats (Benson \& Harada 1988, Blüthgen \& Feldhaar 2010). Arboreal nests are more subject to temperature fluctuations along the year, particularly the harsh winter, which few species are able to withstand. In our site, arboreal pitfalls had low effect in total richness. In the mixed forest, only two species were found exclusively in arboreal pitfalls, all others also occurring on the ground. With pitfalls located at $1.5 \mathrm{~m}$ high, it is expected to find several ground species which climb up trees to forage. However, the low efficiency of the pitfalls and lack of exclusive species suggests a relatively small arboreal community. In grasslands, it was also observed that few species occur exclusively in vegetation (Dröse et al. 2017). Most plants in this habitat do not provide proper nesting sites above the ground, and these would be even more affected by cold temperatures. 
While richness was similar, our results indicate that grassland and forest habitats maintain different ant assemblages. This division was confirmed by the GLM , although it was not very strong (see axis values in Figure 3) and composition overlapped at many points. Two-thirds of the species were exclusive to one habitat, which accounted for about half of the total for each habitat. This finding agrees with the idea that ants have close relationships with vegetation structure, and, consequently, with microhabitat conditions and resources available, such as nesting sites and nutritional supplies (Rico-Gray \& Oliveira 2007, Blüthgen \& Feldhaar 2010, Gibb \& Parr 2010). Indeed, most studies comparing ant species composition between different ecosystems found great dissimilarities (Marques \& Del-Claro 2006, Vasconcelos \& Vilhena 2006, Vasconcelos et al. 2008, Groc et al. 2014).

\section{Concluding remarks}

Here we assessed the ant community in highlands of the state of Santa Catarina, and showed that grasslands and forests harbor similar richness, yet distinct ant species composition. This work joins recent studies that assessed ant communities in the grassland/mixed forest mosaics of the southern Atlantic forest (Pinheiro et al. 2010, Dröse et al. 2017, Franco \& Feitosa 2018). Our results provide insights on the drivers of community organization, and suggest that the combination of relatively high latitude and altitude gives to the ant community some features of temperate habitats, thus distinct from the dense Atlantic Forest and from most Brazilian ecosystems. Such patterns might be context-dependent, and more factors could be involved in the distribution of the biodiversity in this ecosystem, e.g. edge effects (Pinheiro et al. 2010). Nevertheless, we suggest that these grasslands and forests are equally relevant for biodiversity conservation. We call special attention to grasslands, because they are frequently neglected in conservation programs (Overbeck et al. 2015), a conclusion shared by the aforementioned recent studies in the same ecosystem. While grasslands occupy nearly 13.7 million ha in Brazilian territory, less than $0.5 \%$ of the ecosystem is within protected areas (Overbeck et al. 2007). As highlighted by some authors, managed grasslands lead to different plant and ant assemblages, and more research is necessary to effectively protect the biodiversity linked with those habitats (Azcárate $\&$ Peco 2012). Even though the issues in conservation status of plant species have been raised for over a decade (Overbeck et al. 2007), more recently attention has also been called for arthropod diversity in similar ecosystems around the world (Littlewood et al. 2012).

\section{Supplementary material}

The following online material is available for this article:

Figure S1 - Map of the sample grid established in "Parque Nacional de São Joaquim". The rectangular line shows the main trails of the $5 \times 1$ $\mathrm{km}$ grid. Red lines indicate $250 \mathrm{~m}$ plots, which follow the isocline of the ground. The thick yellow line shows the limits of the protected area.

Figure S2 - Schematic representation of the sample design.

\section{Acknowledgements}

We thank Wesley Duarte da Rocha, Rodrigo Feitosa and other researches of the PPBio Mata Atlântica for discussing the sampling protocol. Bruno Bicudo Lippi, Bruno Acioli Casas Souza, Daniel
Barbosa Capella, Huberto Luis Klunk, Juliana Anselmo Florencio and Vítor Carvalho Rocha for assistance in fieldwork. David Warton for help with statistical analysis. Rodrigo Feitosa, John Lattke, Thiago Silva, Mayron Escárraga and Alexandre Ferreira for help with species identification. Rafael Barbizan Sühs for supplying information on vegetation structure for sampled plots. We acknowledge $\mathrm{CNPq}$ for financial support to "PPBio da Mata Atlântica" project (CNPq 457451/2012-9), and also support by the German Research Foundation and the Open Access Publishing Fund of Technische Universität Darmstadt. Cristian L. Klunk was supported by "Programa de Educação Tutorial" (PET - MEC/SESU) and Eduardo L. H. Giehl was supported by CAPES. The authors declare no conflicts of interest.

\section{Author Contributions}

Cristian Luan Klunk: Contribution to data collection; contribution to data analysis and interpretation; contribution to manuscript preparation; contribution to critical revision, adding intellectual content.

Eduardo Luís Hettwer Giehl: Contribution to data analysis and interpretation; contribution to manuscript preparation; contribution to critical revision, adding intellectual content.

Benedito Cortês Lopes: Substantial contribution in the concept and design of the study; contribution to data analysis and interpretation; contribution to critical revision, adding intellectual content.

Frederico Rottgers Marcineiro: Contribution to data collection; contribution to critical revision, adding intellectual content.

Félix Baumgarten Rosumek: Substantial contribution in the concept and design of the study; contribution to data collection; contribution to data analysis and interpretation; contribution to manuscript preparation; contribution to critical revision, adding intellectual content.

\section{Conflicts of interest}

The authors declare that they have no conflict of interest related to the publication of this manuscript.

\section{References}

AGOSTI, D., MAJER, J.D., ALONSO, L.E. \& SCHULTZ, T.R. 2000. Ants: standard methods for measuring and monitoring biodiversity. 1 ed. Smithsonian Institution Press, Washington.

ALBUQUERQUE, N.L. \& BRANDÃO, C.R.F. 2004. A revision of the Neotropical Solenopsidini ant genus Oxyepoecus Santschi, 1926 (Hymenoptera: Formicidae: Myrmicinae). 1. The Vezenyii species-group. Papéis Avulsos de Zoologia (São Paulo) 44(4): 55-80.

ALBUQUERQUE, N.L. \& BRANDÃO, C.R.F. 2009. A revision of the Neotropical Solenopsidini ant genus Oxyepoecus Santschi, 1926 (Hymenoptera: Formicidae: Myrmicinae). 2. Final. Key for species and revision of the Rastratus species-group. Papéis Avulsos de Zoologia (São Paulo) 49(23): 289-309.

ALBUQUERQUE, E.Z. \& DIEHL, E. 2009. Análise faunística das formigas epígeas (Hymenoptera: Formicidae) em campo nativo no planalto das Araucárias, Rio Grande do Sul. Rev. Bras. Entomol. 53(3): 398-403.

ALONSO, L.E. \& AGOSTI, E.D. 2000. Biodiversity studies, monitoring and ants: an overview. In Ants: standard methods for measuring and monitoring biodiversity (D. Agosti, J.D. Majer, L.E. Alonso \& T.R. Schultz, eds.). Smithsonian Institution Press, Washington, p. 1-8.

AlVARES, C.A., STAPE, J.L., SENTElhas, P.C., DE MORAES, G., LEONARDO, J. \& SPAROVEK, G. 2014. Köppen's climate classification map for Brazil. Meteorol. Z. 22(6): 711-728. 
ANDERSEN, A.N. 1986. Diversity, seasonality and community organization of ants at adjacent Heath and Woodland sites in South-Eastern Australia Aust. J. Zool. 34(1): 53-64.

ANTWEB. www.antweb.org (last access in 01/SET/2017)

ARIAS-PENNA, T.M. \& FERNÁNDEZ, F. 2008. Subfamilia Heteroponerinae. In Sistemática, biogeografia y conservación de las hormigas cazadoras de Colombia (E. Jiménez, F. Fernández, T.M. Arias \& F.H. Lozano-Zambrano, eds.). Instituto de Investigación de Recursos Biológicos Alexander von Humboldt, Bogotá, p. 109-117.

AUGUST, P.V. 1983. The role of habitat complexity and heterogeneity in structuring tropical mammal communities. Ecology 64(6): 1495-1507.

AZCÁRATE, F.M. \& PECO, B. 2012. Abandonment of grazing in a mediterranean grassland area: consequences for ant assemblages. Insect Conserv. Diver. 5(4): 279-288.

BEHLING, H. \& PILLAR, V.D. 2007. Late Quaternary vegetation, biodiversity and fire dynamics on the southern Brazilian highland and their implication for conservation and management of modern Araucaria forest and grassland ecosystems. Philos. T. Roy. Soc. B 362(1478): 243-251.

BENSON, W. \& HARADA, A.Y. 1988. Local diversity of tropical and temperature ant faunas (Hymenoptera, Formicidae). Acta Amazon. 18(34): $275-289$

BESTELMEYER, B.T., AGOSTI, D., ALONSO, L.E., BRANDÃO, C.R.F., BROWN JR, W.L., DELABIE, J.H.C. \& SILVESTRE, E.R. 2000. Field techniques for the study of ground-dwelling ants: an overview, description and evaluation. In Ants: standard methods for measuring and monitoring biodiversity (D. Agosti, J.D. Majer, L.E. Alonso \& T.R. Schultz, eds.). Smithsonian Institution Press, Washington, p. 122-144.

BLÜTHGEN, N. \& FELDHAAR, H. 2010. Food and shelter: how resources influence ant ecology. In Ant ecology (L. Lach, C.L. Parr \& K.L. Abbott, eds.). Oxford University Press Inc., New York, p. 115-136.

BOLTON, B. 2000. The ant tribe Dacetini. Memoirs of the American Entomological Institute 65(1): 1-1028.

BOLTON, B. 2017. An online catalog of the ants of the world. antcat.org (last access in 15/DEC/2017)

BOND, W.J. \& PARR, C.L. 2010. Beyond the forest edge: Ecology, diversity and conservation of the grassy biomes. Biol. Conserv. 143(10): 2395-2404.

CHAO, A., GOTELLI, N.J., HSIEH, T.C., SANDER, E.L., MA, K.H., COLWELL, R.K. \& ELLISON, A.M. 2014. Rarefaction and extrapolation with Hill numbers: a framework for sampling and estimation in species diversity studies. Ecol. Monogr. 84(1): 45-67.

COLWELl, R.K., CHAO, A., GOTELLI, N.J., LIN, S.Y., MAO, C.X., CHAZDON, R.L. \& LONGINO, J.T. 2012. Models and estimators linking individual-based and sample-based rarefaction, extrapolation and comparison of assemblages. J. Plant Ecol. 5(1): 3-21.

CUEZZO, F., CALCATERRA, L.A., CHIFFLET, L. \& FOLLETT, P. 2015. Wasmannia Forel (Hymenoptera: Formicidae: Myrmicinae) in Argentina: systematics and distribution. Sociobiology 62(2): 246-265.

DIEHL, E., DIEHL-FLEIG, E., ALBUQUERQUE, E.Z. \& JUNQUEIRA, L.K. 2014. Richness of termites and ants in the State of Rio Grande do Sul, Southern Brazil. Sociobiology 61(2): 145-154.

DRÖSE, W., PODGAISKI, L.R., CAVALLERI, A., FEITOSA, R.M. \& MENDONÇA JR., M.S. 2017. Ground-Dwelling and Vegetation Ant Fauna in South Brazilian Grasslands. Sociobiology 64(4): 381-392.

FARJI-BRENER, A.G., BARRANTES, G. \& RUGGIERO, A. 2004 Environmental rugosity, body size and access to food: a test of the size-grain hypothesis in tropical litter ants. Oikos 104(1): 165-171.

FERNANDES, L.A. \& OMENA, M. 2015. Caracterização básica. 1 ed. Ministério do Meio Ambiente, Urubici.

FERNÁNDEZ, F. 2008 Subfamilia Ponerinae s. str. In Sistemática, biogeografia y conservación de las hormigas cazadoras de Colombia (E. Jiménez, F. Fernández, T.M. Arias \& F.H. Lozano-Zambrano, eds.). Instituto de Investigación de Recursos Biológicos Alexander von Humboldt, Bogotá, p. $123-218$
FISHER, B.L. 1999. Improving inventory efficiency: a case study of leaf-litter ant diversity in Madagascar. Ecol. Appl. 9(2): 714-731.

FRANCO, W. \& FEITOSA, R.M. 2018. First standardized inventory of ants (Hymenoptera: Formicidae) in the natural grasslands of Paraná: New records for Southern Brazil. Papéis Avulsos de Zoologia (São Paulo) 58: 12-19.

FREITAS, J.M.S., DELABIE, J.H.C. \& LACAU, S. 2014. Composition and diversity of ant species into leaf litter of two fragments of a Semi-Deciduous Seasonal Forest in the Atlantic Forest biome in Barra do Choça, Bahia, Brazil. Sociobiology 61(1): 9-20.

GASPER, A.L., SEVEGNANI, L., VIBRANS, A.C., SOBRAL, M., UHLMANN, A., LINGNER, D.V., RIGON-JÚNIOR, M.J., VERDI, M., STIVAL-SANTOS, A., DREVECK, S. \& KORTE, A. 2013. Inventário florístico florestal de Santa Catarina: espécies da Floresta Ombrófila Mista - Flora of the mixed ombrophyllous forest in Santa Catarina state, according of the forest and floristic inventory of Santa Catarina. Rodriguesia 64(2): 201-210.

GIBB, H. \& PARR, C.L. 2010. How does habitat complexity affect ant foraging success? A test using functional measures on three continents. Oecologia 164(4): 1061-1073.

GONÇALVES, C.R. 1961. O gênero Acromyrmex no Brasil (Hym. Formicidae). Studia Entomologica 4(1-4): 113-180.

GROC, S., DELABIE, J.H.C., FERNÁNDEZ, F., LEPONCE, M., ORIVEL, J., SILVESTRE, R., VASCONCELOS, H.L. \& DEJEAN, A. 2014. Leaflitter ant communities (Hymenoptera: Formicidae) in a pristine Guianese rainforest: stable functional structure versus high species turnover. Myrmecol. News 19: 43-51.

HSIEH, T.C., MA, K.H. \& CHAO, A. 2016. iNEXT: an R package for rarefaction and extrapolation of species diversity (Hill numbers). Methods Ecol Evol. 7(12): 1451-1456.

IBGE 2012. Manual Técnico da Vegetação Brasileira. 2 ed. IBGE, Rio de Janeiro.

KETTERL, J., VERHAAGH, M. \& DIETZ, B.H. 2004. Eurhopalothrix depressa sp. n. (Hymenoptera: Formicidae) from Southern Brazil with a key to the Neotropical taxa of the genus. Stud. Neotrop. Fauna E. 39(1): 45-48.

KING, J.R. \& PORTER, S.D. 2005. Evaluation of sampling methods and species richness estimators for ants in upland ecosystems in Florida. Entomological Society of America 34(6): 1566-1578.

KLEIN, R.M. 1978. Mapa fitogeográfico do estado de Santa Catarina. In Flora Ilustrada Catarinense (P.R. Reitz, ed.). FATMA \& Herbário Barbosa Rodrigues, Florianópolis, p. 1-24

LASSAU, S.A. \& HOCHULI, D.F. 2004. Effects of habitat complexity on ant assemblages. Ecography 27(2): 157-164.

LATTKE, J.E. 1995. Revision of the ant genus Gnamptogenys in the New World (Hymenoptera: Formicidae). J. Hymenop. Res. 4: 137-193.

LATTKE, J.E., FERNÁNDEZ, F. \& PALACIO, E.E. 2007. Identification of the species of Gnamptogenys Roger in the Americas. In Advances in ant systematics (Hymenoptera: Formicidae): homage to E. O. Wilson - 50 years of contributions, 80 (R.R. Snelling, B.L. Fisher \& P.S. Ward, eds.). Memoirs of the American Entomological Institute, Gainesville, p. 254-270.

LEWINSOHN, M.T. \& PRADO, P.I. 2003. Biodiversity of Brazil: a synthesis of the current state of knowledge. In Evaluation of the state of knowledge on biological diversity in Brazil: Executive Summary (MMA, ed.). MMA, Brasília, p. 11-20.

LITTLEWOOD, N.A., STEWART, A.J.A. \& WOODCOCK, B.A. 2012. Science into practice - how can fundamental science contribute to better management of grasslands for invertebrates? Insect Conserv. Diver. 5(1): 1-8.

LONGINO, J.T. 2000. What to do with the data. In Ants: standard methods for measuring and monitoring biodiversity (D. Agosti, J.D. Majer, L.E. Alonso \& T.R. Schultz, eds.). Smithsonian Institution Press, Washington, p. 186-203.

LONGINO, J.T. 2013a. A review of the Central American and Caribbean species of the ant genus Eurhopalothrix Brown and Kempf, 1961 (Hymenoptera, Formicidae), with a key to New World species. Zootaxa 3693(2): 101-151.

LONGINO, J.T. 2013b. A revision of the ant genus Octostruma Forel, 1912 (Hymenoptera, Formicidae). Zootaxa 3699(1): 1-61. 
LONGINO, J.T., BRANSTETTER, M.G. \& COLWELL, R.K. 2014. How ants drop out: ant abundance in tropical mountains. Plos One 9(8): 1-9.

LONGINO, J.T. \& FERNÁNDEZ, F. 2007. Taxonomic review of the genus Wasmannia. In Advances in ant systematics (Hymenoptera: Formicidae): homage to E. O. Wilson - 50 years of contributions, 80. (R.R. Snelling, B.L. Fisher \& P.S. Ward, eds.). Memoirs of the American Entomological Institute, Gainesville, p. 271-289.

LOPES, C.T. \& VASCONCELOS, H.L. 2008. Evaluation of three methods for sampling ground-dwelling ants in the Brazilian Cerrado. Neotrop. Entomol 37(4): 399-405.

MAGNUSSON, W.E., LIM, A.P., LUIZÃO, R., LUIZÃO, F., COSTA, F.R.C., CASTILHO, C.V. \& KINUPP, V.F. 2005. RAPELD: uma modificação do método de Gentry para inventários de biodiversidade em sítios para pesquisa ecológica de longa duração. Biota Neotrop. 5(2): 1-6.

MAJER, J.D., DELABIE, J.H.C. \& MCKENZIE, N.L. 1997. Ant litter fauna of forest, forest edges and adjacent grassland in the Atlantic rain forest region of Bahia, Brazil. Insect. Soc. 44(3): 255-266.

MARQUES, G.D.V. \& DEL-CLARO, K. 2006. The ant fauna in a Cerrado area: the influence of vegetation structure and seasonality (Hymenoptera: Formicidae). Sociobiology 47(1): 1-18.

MAYHÉ-NUNES, A.J. \& BRANDÃO, C.R.F. 2005. Revisionary studies on the attine ant genus Trachymyrmex Forel. Part 2: the Iheringi group (Hymenoptera: Formicidae). Sociobiology 45(2): 271-305.

MEDEIROS, F.N.S. \& OLIVEIRA P.S. 2009. Season-dependent foraging patterns case study of a Neotropical forest-dwelling ant (Pachycondyla striata; Ponerinae). In Food exploitation by social insects: ecological, behavioral, and theoretical approaches (S. Jarau \& M. Hrncir, eds.). Taylor \& Francis Group, Boca Raton, p. 81-95.

MILANI, E.J., MELO, J.H.G., SOUZA, P.A., FERNANDES, L.A. \& FRANCA, A.B. 2007. Bacia do Paraná. Boletim de Geociências da PETROBRÁS 15(2): 265-287.

MYERS, N., MITTERMEIER, R.A., MITTERMEIER, C.G., FONSECA, G.A.B. \& KENT, J. 2000. Biodiversity hotspots for conservation priorities. Nature 403: 853-858.

NESS, J., MOONEY, K. \& LACH, L. 2010. Ants as mutualists. In Ant ecology (L. Lach, C.L. Parr \& K.L. Abbott, eds.). Oxford University Press Inc., New York, p. 97-114.

NEVES, F.S., QUEIROZ-DANTAS, K.S., DA ROCHA, W.D. \& DELABIE, J.H.C. 2013. Ants of three adjacent habitats of a transition region between the Cerrado and Caatinga biomes: the effects of heterogeneity and variation in canopy cover. Neotrop. Entomol. 42(3): 258-268.

NIMER, E. 1989. Climatologia do Brasil. 2 ed. Departamento de Recursos Naturais e Estudos Ambientais - IBGE, Rio de Janeiro.

OKSANEN, J., BLANCHET, F.G., KINDT, R., LEGENDRE, P., MINCHIN, P.R., O'HARA, R.B., SIMPSON, G.L., SOLYMOS, P., STEVENS, M.H.H. \& WAGNER, H. 2016. Vegan: Community Ecology Package. R package version 2.3-5.

OVERBECK, G.E., MÜLLER, S.C., FIDELIS, A., PFADENHAUER, J., PILLAR, V.D., BLANCO, C.C., BOLDRINI, I.I., BOTH, R. \& FORNECK, E.D. 2007. Brazil’s neglected biome: The South Brazilian Campos. Perspec. Plant Ecol. 9(2): 101-116.

OVERBECK, G.E., VÉLEZ-MARTIN, E., SCARANO, F.R., LEWINSOHN, T.M., FONSECA, C.R., MEYER, S.T., MÜLLER, S.C., CEOTTO, P., DADALT, L., DURIGAN, G., GANADE, G., GOSSNER, M.M., GUADAGNIN, D.L., LORENZEN, K., JACOBI, C.M., WEISSER, W.W. \& PILLAR, V.D. 2015. Conservation in Brazil needs to include non-forest ecosystems. Diversity and Distrib, 21(12): 1455-1460.
PALACIO, E.E. \& FERNÁNDEZ, F. 2003. Claves para las subfamílias y géneros. In Introducción a las hormigas de la región Neotropical (F. Fernández, ed.). Instituto de Investigación de Recursos Biológicos Alexander von Humboldt, Bogotá, p. 233-260.

PIE, M.R. 2016. The macroevolution of climatic niches and its role in ant diversification. Ecol. Entomol. 41(3): 301-307.

PINHEIRO, E.R.S., DUARTE, L.S., DIEHL, E. \& HARTZ, S.M. 2010. Edge effects on epigeic ant assemblages in a grassland-forest mosaic in southern Brazil. Acta Oecol. 36(4): 365-371.

R CORE TEAM 2016. R: A language and environment for statistical computing. R Foundation for Statistical Computing, Vienna, Austria.

RICO-GRAY, V. \& OLIVEIRA, P.S. 2007. The ecology and evolution of antplant interactions. 1 ed. University of Chicago Press, Chicago.

ROSADO, J.L.O., GONÇALVES, M.G., DRÖSE, W., SILVA, E.J.E., KRÜGER, R.F., FEITOSA, R.M. \& LOECK, A.E. 2012. Epigeic ants (Hymenoptera: Formicidae) in vineyards and grassland areas in the Campanha region state of Rio Grande do Sul, Brazil. Check List 8(6): 1184-1189.

ROSUMEK, F.B., ULYSSÉA, M.A., LOPES, B.C., STEINER, J. \& ZILLIKENS, A. 2008. Formigas de solo e de bromélias em uma área de Mata Atlântica, Ilha de Santa Catarina, sul do Brasil: levantamento de espécies e novos registros. Biotemas 21(4): 81-89.

SABU, T.K., SHIJU, R.T., VINOD, K.V. \& NITHYA, S. 2011. A comparison of the pitfall trap, Winkler extractor and Berlese funnel for sampling ground-dwelling arthropods in tropical montane cloud forests. J. Insect Sci. 11(28): 1-19.

SEIFERT, B. 2007. Die Ameisen Mittel- und Nordeuropas. 1 ed. Lutra, Tauer.

SILVA, L.C.R. \& ANAND, M. 2011. Mechanisms of Araucaria (Atlantic) Forest Expansion into Southern Brazilian Grasslands. Ecosystems 14(8): 1354-1371

SILVA, R.R. \& BRANDÃO, C.R.F. 2014. Ecosystem-wide morphological structure of leaf-litter ant communities along a tropical latitudinal gradient PloS one 9(3): 1-11.

SILVA, R.R. \& LOPES, B.C. 1997. Ants (Hymenoptera: Formicidae) for Atlantic rainforest at Santa Catarina Island, Brazil: two years of sampling. Rev. Biol. Trop. 45(4): 1641-1648.

ULYSSÉA, M.A., CERETO, C.E., ROSUMEK, F.B., SILVA, R.R. \& LOPES, B.C. 2011. Updated list of ant species (Hymenoptera, Formicidae) recorded in Santa Catarina State, southern Brazil, with a discussion of research advances and priorities. Rev Bras. Entomol. 55(4): 603-611.

VASCONCELOS, H.L., LEITE, M.F., VILHENA, J.M.S., LIMA, A.P. \& MAGNUSSON, W.E. 2008. Ant diversity in an Amazonian savanna: Relationship with vegetation structure, disturbance by fire, and dominant ants. Austral Ecol. 33(2): 221-231.

VASCONCELOS, H.L. \& VILHENA, J.M.S. 2006. Species turnover and vertical partitioning of ant assemblages in the Brazilian Amazon: a comparison of Forests and Savannas. Biotropica 38(1): 100-106.

WANG, Y., NAUMANN, U., WRIGHT, S.T. \& WARTON, D.I. 2012. mvabund - an R package for model-based analysis of multivariate abundance data. Methods Ecol. Evol. 3(3): 471-474.

WATKINS, J.F. 1976. The identification and distribution of New World army ants (Dorylinae: Formicidae). 1 ed. Baylor University Press, Waco.

WILD, A.L. 2007. Taxonomic revision of the ant genus Linepithema (Hymenoptera: Formicidae). University of California Publications in Entomology 126: 1-151.

WILSON, E.O. 2003. Pheidole in the New World. A dominant, hyperdiverse ant genus. 1 ed. Harvard University Press, Massachussets. 